\title{
THE
}

\section{Measurements of tropospheric nitric acid over the western United States and northeastern Pacific Ocean}

\author{
P. J. LeBel \\ B. J. Huebert \\ University of Rhode Island \\ H. I. Schiff \\ S. A. Vay \\ S. E. VanBramer
}

See next page for additional authors

Follow this and additional works at: https://digitalcommons.uri.edu/gsofacpubs

Terms of Use

All rights reserved under copyright.

\section{Citation/Publisher Attribution}

LeBel, P. J., B. J. Huebert, H. I. Schiff, S. A. Vay, S. E. VanBramer, and D. R. Hastie (1990), Measurements of tropospheric nitric acid over the western United States and northeastern Pacific Ocean, J. Geophys. Res., 95(D7), 10199-10204, doi: 10.1029/JD095iD07p1019.

Available at: http://dx.doi.org/10.1029/JD095iD07p10199

This Article is brought to you for free and open access by the Graduate School of Oceanography at DigitalCommons@URI. It has been accepted for inclusion in Graduate School of Oceanography Faculty Publications by an authorized administrator of DigitalCommons@URI. For more information, please contact digitalcommons-group@uri.edu. 


\section{Authors}

P. J. LeBel, B. J. Huebert, H. I. Schiff, S. A. Vay, S. E. VanBramer, and D. R. Hastie

This article is available at DigitalCommons@URI: https://digitalcommons.uri.edu/gsofacpubs/204 


\section{MEASUREMENTS OF TROPOSPHERIC NITRIC ACID OVER THE WESTERN UNITED STATES AND NORTHEASTERN PACIFIC OCEAN}

P. J. LeBe1, 1 B. J. Huebert,,$^{2}$ H. I. Schiff, ${ }^{3}$ S. A. Vay, 1
S. E. VanBramer, ${ }^{4}$ and D. R. Hastie

\begin{abstract}
During the August-September 1986 GTE/CITE 2 aircraft mission, more than 240 measurements of nitric acid $\left(\mathrm{HNO}_{3}\right)$ were made in the free troposphere as well as in the boundary layer over the northeastern Pacific Ocean and western continental United States. Marine $\mathrm{HNO}_{3}$ measurement results were strikingly similar to results from GAMETAG and other past atmospheric field experiments. The marine boundary layer $\mathrm{HNO}_{3}$ average, 62 parts per trillion by volume (pptv), was one third lower than the marine free tropospheric average, 108 pptv, suggesting that the boundary layer is a sink for tropospheric nitric acid, probably by dry deposition. Nitric acid measurements on a nighttime continental flight gave a free tropospheric average of 218 pptv, substantially greater than the daytime continental free tropospheric five-flight average of 61 pptv. However, the nighttime results may have been influenced by highly convective conditions that existed from thunderstorms in the vicinity during that night flight. Our continental boundary layer $\mathrm{HNO}_{3}$ average of $767 \mathrm{pptv}$ is an order of magnitude greater than the free tropospheric average, indicating that the boundary layer is a source of free tropospheric $\mathrm{HNO}_{3}$. The distribution of continental boundary layer $\mathrm{HNO}_{3}$ data, from averages of 123 pptv over rural Nevada and Utah to 1057 pptv in the polluted San Joaquin Valley of California suggests a close tie between boundary layer $\mathrm{HNO}_{3}$ and anthropogenic activity.
\end{abstract}

\section{Introduction}

Nitric acid $\left(\mathrm{HNO}_{3}\right)$ is one of the most abundant trace nitrogen species in the troposphere. A reactive nitrogen species, $\mathrm{HNO}_{3}$ plays a key role in the photochemistry and chemistry of the troposphere as well as in the biogeochemical cycling of nitrogen between the atmosphere and the biosphere [Levine, 1984; Logan et al., 1981; Stedman and Shetter, 1983]. In addition, $\mathrm{HNO}_{3}$ is a rapidly growing component of acid precipitation [Galloway and Likens, 1981]. The atmospheric removal of $\mathrm{HNO}_{3}$ by rainout or dry deposition is the major sink for $\mathrm{NO}_{x}$ in the troposphere

1 NASA Langley Research Center, Hampton, Virginia. 2 Center for Atmospheric Chemistry Studies, Graduate School of Oceanography, University of Rhode Island, Narragansett.

3 Department of Chemistry, York University, North York, Ontario, Canada.

4 Department of Chemistry, Colorado College, Colorado Springs.

Copyright 1990 by the American Geophysical Union.

Paper number 89JDO1148.

0148-0227/90/89JD-01148\$05.00
[Logan, 1983]. Unfortunately, knowledge of the chemistry and photochemistry of $\mathrm{HNO}_{3}$ and other reactive nitrogen species is 1 imited by the availability of techniques capable of rapid, reliable measurements at low species concentrations. To assess the capabilities of existing and emerging measurement technology, an aircraft intercomparison of $\mathrm{HNO}_{3}$ sensing techniques was undertaken as part of the Chemical Instrumentation Test and Evaluation (CITE 2) mission under the auspices of the NASA Global Tropospheric Experiment (GTE) project.

The CITE 2 flight mission took place over the western United States and northeastern Pacific Ocean during August/September 1986. CITE 2 involved measurement of a number of atmospheric chemical species and meteoralogical parameters with several scientific and instrument related goals [Hoell et al., this issue]. This paper describes the results of the measurement of $\mathrm{HNO}_{3}$ during CITE 2. A companion paper [Huebert et al., this issue] relates $\mathrm{HNO}_{3}$ concentrations to $\mathrm{NO}_{x}$ concentrations measured in several different regimes. A related paper [Gregory et al., this issue] describes the intercomparison of three $\mathrm{HNO}_{3}$ measurement techniques during CITE 2 .

\section{Experimenta1}

On August 11, 1986, the NASA Electra aircraft departed Wallops Flight Facility (WFF), Wallops Island, Virginia, on a transcontinental flight to Ames Research Center, Moffett Field, California. The two legs of this flight, with a refueling stop at Wichita, Kansas, represented the first two CITE 2 data-taking missions. Moffett Field, located approximately $50 \mathrm{~km}$ southeast of San Francisco, was the base for nine additional missions between August 15 and September 2. These flights, typically 5 hours in duration and covering a radius up to $800 \mathrm{~km}$ from Moffett $F i e l d$, included both continental and marine, free troposphere and boundary layer regimes. While most flights took place during midmorning to midafternoon, one nighttime mission was also undertaken. On September 5, 1986, the aircraft departed Moffett Field on a return transcontinental flight to WFF, with a refueling stop at Oklahoma City, Oklahoma. Further details of each flight mission including specific flight paths can be found in the paper by Hoell et al. [this issue]. Meteorological conditions during CITE 2 are described by Shiphan et al. [this issue].

The CITE 2 nitric acid measurement techniques included a tungsten oxide denuder sampler (DENUDER) (NASA Langley Research Center, P. J. LeBel, principal investigator), a Teflon/nylon filter pack sampler (FILTER) (Stanford Research Institute, B. J. Huebert, principal investigator), and a tunable diode laser spectrometer (TDL) (York University, H. Schiff, principal investigator). The denuder sampler [Braman et al., 1982; LeBel et 
TABLE 1. Characteristics of $\mathrm{HNO}_{3}$ Instruments

\begin{tabular}{lcccc}
\hline \multicolumn{1}{c}{ Technique } & $\begin{array}{c}\text { Integration } \\
\text { Time }\end{array}$ & $\begin{array}{c}\text { Detection } \\
\text { Limit }\end{array}$ & Accuracy, $\%$ & Precision, \% \\
\hline $\begin{array}{l}\text { Tungsten oxide } \\
\text { denuder/chemilumi- } \\
\text { nescence }\end{array}$ & $5-10 \mathrm{~min}$ & $\begin{array}{l}20 \text { pptv } \\
(10 \mathrm{~min})\end{array}$ & $15-20$ & 8 \\
$\begin{array}{l}\text { Nylon filter/ion } \\
\text { chromatography }\end{array}$ & $0.5-2$ hours & $\begin{array}{l}8 \text { pptv } \\
(1.5 \text { hours })\end{array}$ & 20 & 10 \\
Tunable diode laser & $2-3$ min & $\begin{array}{l}75 \text { pptv } \\
(3 \mathrm{~min})\end{array}$ & 15 & 10 \\
\hline
\end{tabular}

al., 1985] consisted of a 6-mm on quartz tube with an interior coating of tungsten oxide to chemisorb $\mathrm{HNO}_{3}$ in an atmospheric sample. Typical sampling times were 5-10 min. Collected samples were analyzed on board the aircraft immediately after collection. Sample analysis involved thermal desorption of collected $\mathrm{HNO}_{3}$ as nitric oxide (NO) and detection by chemiluminescent reaction of NO with ozone [Bollinger, 1982]. The filter pack sampler [Goldan et al., 1983] consisted of two 90-mm-diameter filters, a Teflon prefilter to retain aerosols followed by a nylon filter to collect $\mathrm{HNO}_{3}$. Typical filter pack sampling times were $1 / 2$ to 2 hours. Filters were analyzed after completion of each flight, generally within 48 hours of collection, by ion chromatography nitrate analysis. The tunable diode laser system [Schiff et al., 1983, 1987, this issue] measured $\mathrm{HNO}_{3}$ directly, in real time, through its absorption of infrared radiation from a lead-salt solid state laser.

Characteristics of the three $\mathrm{HNO}_{3}$ instruments are shown in Table 1. Note that $\mathrm{HNO}_{3}$ detection limits ranged from 8 parts per trillion by volume (pptv) for a 120 min filter sample to $75 \mathrm{pptv}$ for a 3-min TDL sample. The three techniques estimate similar accuracy and precision. Additional details of the measurement techniques can be found in the references cited above as well as in the CITE $2 \mathrm{HNO}_{3}$ instrument intercomparison paper

[Gregory et al., this issue].

Because of the aircraft configuration and space limitations, each $\mathrm{HNO}_{3}$ instrument was located in a different area of the Electra aircraft, and each used its own probe and manifold system to sample outside air. To insure that all instruments were sampling free stream air, the probes were designed to extend beyond the aircraft boundary layer.

More than $240 \mathrm{HNO}_{3}$ measurements were made on 13 flight missions during the $31 / 2$ week CITE 2 experiment. The majority of the $\mathrm{HNO}_{3}$ measurements were made by the denuder and filter instruments; during most of the flight missions the TDL system was dedicated to measurement of nitrogen dioxide. In fact, nearly the entire TDL $\mathrm{HNO}_{3}$ data set comes from measurements during a portion of one flight within the boundary layer of California's San Joaquin Valley. Only the denuder system made measurements during aircraft descents and ascents; these measurements are described 1 ater as "spiral."

\section{Observations}

\section{Marine Free Tropospheric Meagurements}

Nitric acid measurements were made in the marine free troposphere during CITE 2 missions $6,7,8,10$, and 12 over a 2-week period from August 15 to August 30, 1986. Flight routes [Hoell et al., this issue] ranged over the Pacific Ocean from northwest through southwest of Moffett Field. The results of denuder and filter $\mathrm{HNO}_{3}$ measurements made on August 15 during mission 6 are shown in Figure 1. (The horizontal lines on the filter data points indicate the extent of the filter sampling time; the denuder sampling time is less than the width of the data point symbols. Note the excellent agreement between the two techniques on this mission, despite a quite large difference in integration times.) On this flight, two different air masses were encountered, both with significant levels of species suggesting continental origin [Shipham et al., this issue]. During the initial portion of mission 6 the $\mathrm{HNO}_{3}$ levels are high. Further along the flight route we encounter a second air mass with lower, but still significant, $\mathrm{HNO}_{3}$ concentrations. The return flight route, beginning at approximately $2100 \mathrm{GMT}$, retraced the outgoing route and the $\mathrm{HNO}_{3}$ concentrations measured tend to mirror the initial me asurements.

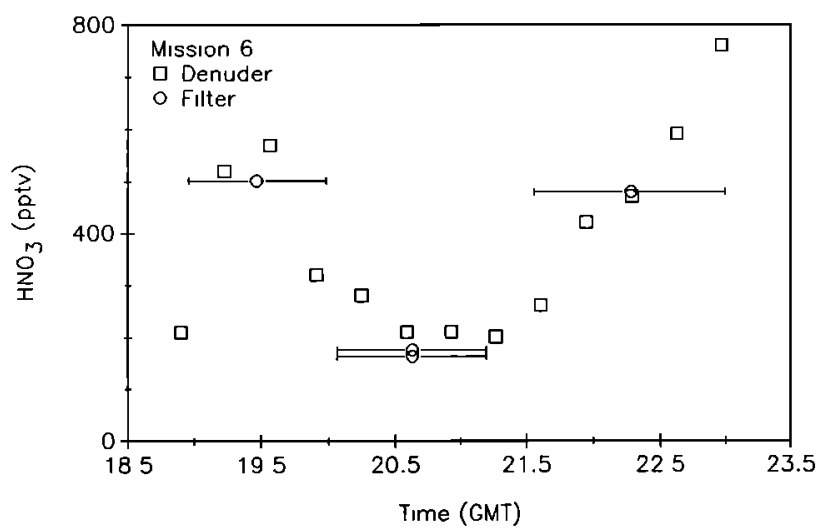

Fig. 1. Marine tropospheric $\mathrm{HNO}_{3}$ concentrations measured by denuder and filter instruments during mission 6 . 
TABLE 2. Summary of $\mathrm{HNO}_{3}$ Marine Measurements

\begin{tabular}{|c|c|c|c|c|c|c|}
\hline \multirow[b]{2}{*}{ Date } & \multirow[b]{2}{*}{$\mathbf{n}$} & \multicolumn{5}{|c|}{ Nitric Acid Concentrations, pptv } \\
\hline & & Minimum & Maximum & Median & Mean & s.d. \\
\hline \multicolumn{7}{|c|}{ Marine Free Troposphere } \\
\hline Aug. 15 & 17 & 162 & 760 & 320 & 372 & 173 \\
\hline Aug. 19 & 12 & 45 & 200 & 95 & 104 & 42 \\
\hline Aug. 21 & 14 & $<20$ & 140 & 60 & 69 & 42 \\
\hline Aug. 26 & 10 & 50 & 136 & 82 & 87 & 23 \\
\hline Aug. 30 & 17 & 30 & 159 & 90 & 92 & 32 \\
\hline & 70 & $<20$ & 760 & 100 & 157 & 152 \\
\hline & 62 & $<20$ & 320 & 90 & 108 & 62 \\
\hline
\end{tabular}

Marine Boundary Layer

\begin{tabular}{|c|c|c|c|c|c|c|c|}
\hline 7 & Aug. 19 & 5 & 38 & 100 & 70 & 69 & 20 \\
\hline 10 & Aug. 26 & 4 & 30 & 104 & 40 & 53 & 29 \\
\hline All data & & 9 & 30 & 104 & 60 & 62 & 26 \\
\hline
\end{tabular}

Here, $\mathrm{n}$ is number of measurements; $\mathbf{s . d .}$ is standard deviation.

The $\mathrm{HNO}_{3}$ marine measurements are summarized in Table 2. If we exclude that portion of the mission 6 data that would appear to have recent continental origin, the 62 remaining $\mathrm{HNO}_{3}$ marine free tropospheric measurements give a mean concentration (108 \pm 62 pptv) remarkably similar to the GAMETAG $\mathrm{HNO}_{3}$ results of $110 \pm 70 \mathrm{pptv}$ [Huebert and Lazrus, 1980]. The results are also in quite good agreement with the $97 \pm 59$ pptv summertime (August) marine tropospheric $\mathrm{HNO}_{3}$ concentration reported from measurements at Mauna Loa Observatory in Hawai i [Galasyn et al., 1987].

\section{Marine Boundary Layer Measurements}

Nine $\mathrm{HNO}_{3}$ measurements were made in the marine boundary layer during missions 7 and 10 (August 19 and 26). The mean measured $\mathrm{HNO}_{3}$ concentration (62 pptv) is in close agreement with GAMETAG results (70 pptv) [Huebert and Lazrus, 1980], but our measurements show less variability ( \pm 26 pptv) than reported for GAMETAG ( $\pm 60 \mathrm{pptv})$. Note that for the two missions ( 7 and 10) with measurements in both free troposphere and boundary layer the marine boundary layer $\mathrm{HNO}_{3}$ concentrations tend to be about one third lower than marine free tropospheric concentrations.

\section{Marine Profiles}

Figure 2 shows $\mathrm{HNO}_{3}$ mixing ratios measured by the denuder instrument during portions of the four marine flights (missions $7,8,10$, and 12), which included a "spiral" altitude change between free troposphere and boundary layer. These flights took place between August 19 and August 30, 1986. Keeping in mind that Figure 2 is not a precise altitude profile because of the instrument's integration time and that the four missions were flown over a 12-day period in somewhat different

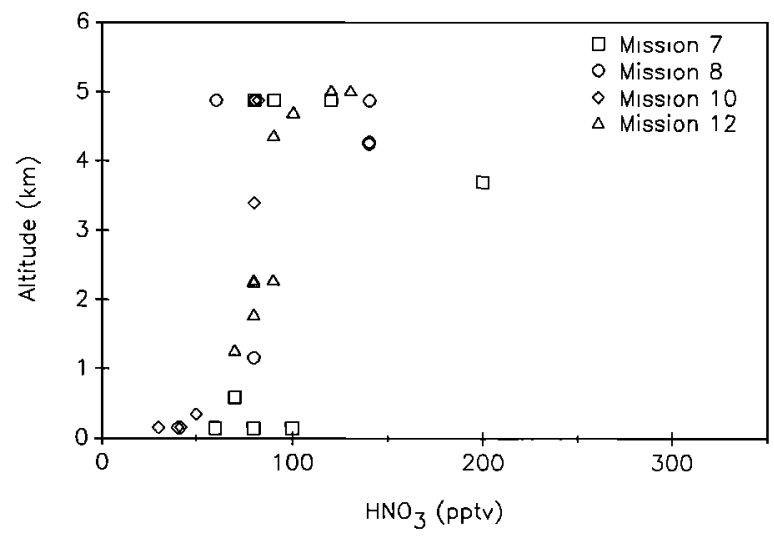

Fig. 2. Marine nitric acid concentrations measured by the denuder instrument during aircraft "spirals" between free troposphere and boundary layer on four CITE 2 missions.

areas, the data show a decrease in $\mathrm{HNO}_{3}$ concentration with decreasing altitude, suggesting a sink for tropospheric $\mathrm{HNO}_{3}$ within the marine boundary layer, probably from dry deposition. While the (mission 7) data point at 200 pptv/3.7 km would seem to be an anomaly, it correlates well with the detailed $\mathrm{NO}_{\mathrm{y}}$ profile measured on mission 7 (G. Huebler, private communication, 1989) which shows a layer of elevated nitrogen species concentrations at that altitude.

\section{Continental Free Tropospheric Measurements}

Nitric acid continental measurements are summarized in Table 3 . Daytime measurements were made during three missions $(11,13$, and 14) from Moffett Field, as well as on the transcontinental 
TABLE 3. Summary of $\mathrm{HNO}_{3}$ Continental Measurements

\begin{tabular}{|c|c|c|c|c|c|c|c|}
\hline \multirow[b]{2}{*}{ Mission } & \multirow[b]{2}{*}{ Date } & \multirow[b]{2}{*}{$\mathbf{n}$} & \multicolumn{5}{|c|}{ Nitric Acid Concentrations, pptv } \\
\hline & & & Minimum & Maximum & Median & Mean & s.d. \\
\hline \multicolumn{8}{|c|}{ Cont inental Free Troposphere } \\
\hline 4,5 & Aug. 11 & 15 & $<20$ & 560 & 128 & 154 & 149 \\
\hline 11 & Aug. 28 & 25 & 20 & 174 & 61 & 73 & 41 \\
\hline 13 & Aug. 30 & 15 & $<20$ & 216 & 80 & 78 & 63 \\
\hline 14 & Sept. 2 & 9 & $<20$ & 70 & 40 & 40 & 22 \\
\hline 15,16 & Sept. 5 & 30 & $<20$ & 153 & 40 & 46 & 35 \\
\hline 9 (night) & Aug. 23-24 & 19 & 140 & 374 & 219 & 218 & 66 \\
\hline All Data & & 113 & $<20$ & 560 & 70 & 99 & 94 \\
\hline Daytime & & 94 & $<20$ & 560 & 58 & 75 & 80 \\
\hline \multicolumn{8}{|c|}{ Western U.S./ } \\
\hline Day & & 67 & $<20$ & 216 & 53 & 61 & 47 \\
\hline Nighttime & & 19 & 140 & 374 & 219 & 218 & 66 \\
\hline \multicolumn{8}{|c|}{ Continental Boundary Layer } \\
\hline 4,5 & Aug. 11 & 10 & 280 & 590 & 470 & 457 & 140 \\
\hline 11 & Aug. 28 & 24 & 300 & 1721 & 988 & 1057 & 437 \\
\hline 14 & Sept. 2 & 6 & 30 & 238 & 120 & 123 & 60 \\
\hline All Data & & 40 & 30 & 1721 & 645 & 767 & 507 \\
\hline
\end{tabular}

Here, $n$ is number of measurements; $\mathbf{s . d .}$ is standard deviation.

flights (missions 4,5 and 15,16 ). Nighttime measurements were made during mission 9 . The result of al1 (113) continental free tropospheric measurements over a $31 / 2$ week period is a mean $\mathrm{HNO}_{3}$ concentration of $99 \pm 94$ pptv. Considering daytime measurements only, 94 measurements give a mean $\mathrm{HNO}_{3}$ concentration of $75 \pm 80 \mathrm{pptv}$. If we eliminate the measurements made over the eastern United States (where significant free tropospheric pollution was encountered on one of the transcontinental flights (see discussion below)), the result is a "western U.S." continental daytime tropospheric $\mathrm{HNO}_{3}$ concentration of $61 \pm 47 \mathrm{pptv}$ based on 67 measurements. By comparison, during the GAMETAG experiment [Huebert and Lazrus, 1980], 23 continental free tropospheric measurements gave an $\mathrm{HNO}_{3}$ concentration of $160 \pm 110$ pptv, nearly 3 times our western U.S. value. Nineteen measurements on August 23-24 during mission 9 established a nighttime $\mathrm{HNO}_{3}$ average of $218 \pm 66$ pptv, nearly 4 times the 61 pptv daytime concentration.

\section{Continental Boundary Layer Measurements}

Continental boundary layer $\mathrm{HNO}_{3}$ measurements were made during three missions. During mission 5 , the western portion of the August 11 transcontinental flight (discussed below), 10 measurements gave a mean $\mathrm{HNO}_{3}$ concentration of $457 \pm 140$ pptv in an elevated boundary layer over the Rocky Mountains. During mission 11 in the polluted San Joaquin Valley boundary layer, 24 measurements resulted in a concentration of $1057 \pm 437$ pptv. During mission 14, six measurements gave a boundary layer $\mathrm{HNO}_{3}$ concentration of $123 \pm 60$ pptv. The mission 14 flight path was east across California and Nevada, including over an hour in the planetary boundary layer, a spiral up to the free troposphere over western Utah, and a return flight leg that retraced the outgoing leg but at an altitude of $6.1 \mathrm{~km}$. The $\mathrm{HNO}_{3}$ concentration measured on this free tropospheric leg was $40 \pm 22$ pptv, one third of the boundary layer concentration. The entire continental boundary layer data set consists of 40 measurements giving a mean $\mathrm{HNO}_{3}$ concentration of $767 \pm 507$ pptv, quite variable, strongly influenced by the San Joaquin Valley measurements and, as expected, significantly higher than the free tropospheric values measured during CITE 2. Nitric acid measurements during GAMETAG showed northern mid-1atitude boundary layer concentrations always greater than 250 pptv [Huebert and Lazrus, 1980]. Our measurements during mission 14 over remote areas of Nevada and Utah showed concentrations always less than 238 pptv. This would suggest that both the CITE 2 $\mathrm{HNO}_{3}$ continental boundary layer results and the GAMETAG results are influenced by choice of sampling location, and that neither is totally representative of the entire northern mid-latitude boundary layer. It does seem clear, from the distribution of $\mathrm{HNO}_{3}$ concentrations on our three boundary layer missions, that $\mathrm{HNO}_{3}$ in the continental boundary layer is closely tied to anthropogenic activities.

\section{Longitudinal Variation}

Figure 3 shows $\mathrm{HNO}_{3}$ mixing ratio versus longitude from denuder and filter measurements during the August 11 (missions 4 and 5) 


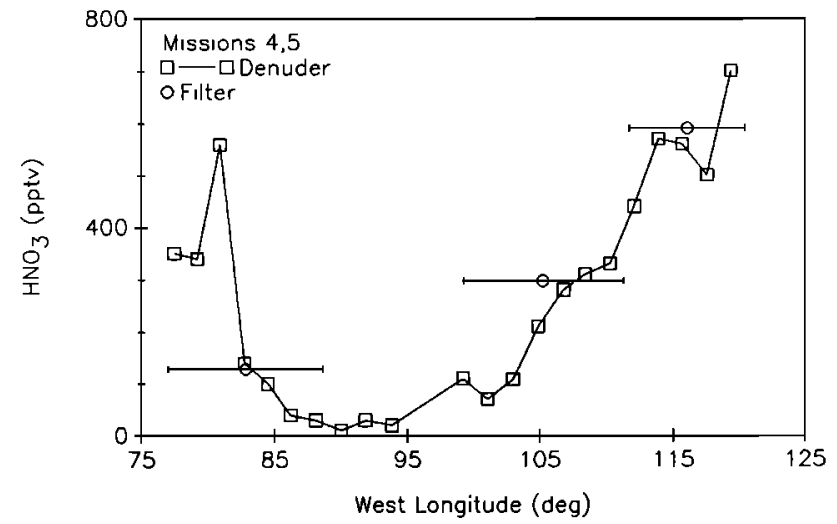

Fig. 3. Longitudinal variability of $\mathrm{HNO}_{3}$ between Wallops Island, Virginia and Moffett Field, California, measured by denuder and filter instruments during the August 11 transcontinental mission.

transcontinental flight from WFF $\left(75.5^{\circ} \mathrm{W}\right.$ longitude) to Moffett Field ( $122^{\circ} \mathrm{W}$ longltude). As in Figure 1 the horizontal 1 ines show the extent of the filter sampling time, with the denuder sampling period hidden by the data point symbols. All measurements were made at an altitude of 4.9 $\mathrm{km}$. During the transcontinental flight we encountered a wide range of $\mathrm{HNO}_{3}$ concentrations, from less than 20 pptv to over 700 pptv. The high concentrations east of longitude $82^{\circ}$ were measured in an air mass that had spent substantial time over the southeastern United States and contained high levels of carbon monoxide and ozone [Shipham et al., this issue]. West of the Appalachian mountains the aircraft penetrated a cold front, and we immediately saw a substantial reduction in $\mathrm{HNO}_{3}$ (and other species as well). Over the Rocky Mountains, significant $\mathrm{HNO}_{3}$ levels were measured, not in tropospheric air but in an elevated planetary boundary layer which the aircraft had penetrated over the mountains [Shipham et al., this issue]. The concentration of $\mathrm{HNO}_{3}$ (and other species) remained elevated through the remainder of the flight. By contrast, the return

transcontinental flight from Moffett Field to WFF, which took place $31 / 2$ weeks later over a similar flight route, showed some of the lowest $\mathrm{HNO}_{3}$ (and other species) free tropospheric concentrations encountered during CITE 2.

\section{Conclusions}

During CITE 2, more than 240 tropospheric nitric acid measurements were made, significantly increasing the available tropospheric $\mathrm{HNO}_{3}$ data base. Approximately one third of the measurements were made over the northeastern Pacific Ocean with the remainder over the continental United States. Our marine results, both free tropospheric and boundary layer, agreed remarkably well with results from the GAMETAG atmospheric experiment conducted 9 years earlier. Our average marine boundary layer $\mathrm{HNO}_{3}$ concentration ( $62 \mathrm{pptv}$ ) was one third lower than the free tropospheric average (108 pptv), indicating a loss of tropospheric $\mathrm{HNO}_{3}$ within the marine boundary layer. Marine and continental free tropospheric concentrations were roughly comparable, although surprisingly, the continental levels were somewhat lower (mean 75 pptv, median 58 pptv) than marine values (mean 157 pptv, median 100 pptv). Our continental free tropospheric $\mathrm{HNO}_{3}$ average is substantially less (by a factor of 3) than the GAMETAG results, perhaps due to the variability of $\mathrm{HNO}_{3}$ with location. Our measured nighttime tropospheric $\mathrm{HNO}_{3}$ average of $218 \pm 66$ pptv is significantly greater than measured daytime values, possibly because the highly convective conditions that existed during that night flight from thunderstorms in the area may have brought boundary layer air into the free troposphere. Like the GAMETAG results our continental boundary layer measurements were much (3-12 times) higher than free tropospheric concentrations suggesting that nitric acid in the boundary layer is a source of free tropospheric $\mathrm{HNO}_{3}$. The distribution of $\mathrm{HNO}_{3}$ in the continental boundary layer from low concentrations in rural areas to much higher concentrations in air coming from a large urban area suggests a close tie between boundary layer $\mathrm{HNO}_{3}$ and anthropogenic activity. We also note that in some of the measurement regimes the standard deviation of the measurements is significant, sometimes comparable to the average. This atmospheric variability has been observed in past field experiments involving measurement of atmospheric $\mathrm{HNO}_{3}$ and is not surprising for $a \mathrm{gas}$ with potential for rapid removal by heterogeneous processes.

Acknowledgments. We are indebted to Roger Navarro and the flight and technical support crew from Wallops Flight Facility and to John Reller and his Ares Research Center coworkers without whose support these measurements would not have been possible. P.J.L. thanks Patricia Roberts and Ralph Marinaro for their help with data analys is and Arnold Torres for helpful discussions. B.J.H. acknowledges financial support for this work from NSF grant ATM-8613121 and NASA research grant NAG-1-572. S.A.V. thanks E. A. Modlin for technical support during the fabrication of CITE 2 aircraft instrumentation.

\section{References}

Bollinger, M. J., Chemiluminescent measurements of the oxides of nitrogen in the clean troposphere and atmospheric chemistry implications, Ph.D. dissertation, Univ. of Colorado, Boulder, 1982.

Braman, R. S., T. J. Shelley, and W. A. McClenny, Tungstic acid for preconcentration and determination of gaseous and particulate ammonia and nitric acid in ambient air, Anal. Chem., 54, 358-364, 1982 .

Galasyn, J. F., K. L. Tschudy, and B. J. Huebert, Seasonal and diurnal variability of nitric acid vapor and ionic aerosol species in the remote free troposphere at Mauna Loa, Hawai i, J. Geophys. Res., 92, 3105-3113, 1987.

Gal loway, J. N. and G. E. Likens, Acid precipitation: The importance of nitric acid, Atmos. Environ. , 15, 1081-1085, 1981.

Goldan, P. D., W. C. Kuster, D. A. Albritton, F. C. Fehsenfeld, P. S. Connell, R. B. Norton, and B. J. Huebert, Calibration and tests of the filter-collection method for measuring clean-air, ambient levels of nitric acid, Atmos. Environ., 17, 1355-1364, 1983.

Gregory, G. L., J. M. Hoel1, Jr., B. J. Huebert, S. E. VanBramer, P. J. LeBel, S. A. Vay., R. 
M. Marinaro, H. I. Schiff, D. R. Hastie, G. I. Mackay, and D. R. Karecki, An intercomparison of airborne nitric acid measurements, J. Geophys. Res., this issue.

Hoe11, J. M. Jr., D. L. Albritton, G. L. Gregory, R. J. McNeal, S. M. Beck, R. J. Bendura, and J. W. Drewry, Operational overview of NASA GTE/CITE 2 airborne instrument intercomparisons: Nitrogen dioxide, nitric acid, and PAN, J. Geophys. Res., this issue.

Huebert, B. J. and A. L. Lazrus, Tropospheric gas-phase and particulate nitrate measurements, J. Geophys. Res., 85, 7322-7328, 1980.

Huebert, B. J., S. F. VanBramer, P. J. LeBel, S. A. Vay, A. L. Torres, H. I. Schiff, D. R. Hastie, G. Hubler, J. D. Bradshaw, M. A. Carrol1, D. D. Davis, R. A. Ridley, M. 0. Rodgers, S. T. Sandholm, and S. Dorris, Measurements of the nitric acid to $\mathrm{NO}_{x}$ ratio in the troposphere, J. Geophys. Res., this issue.

LeBe1, P. J., J. M. Hoel1, J. S. Levine, and S. A. Vay, Aircraft measurements of ammonia and nitric acid in the lower troposphere, Geophrs. Res. Lett., 12, 401-404, 1985.

Levine, J. S., Water and the photochemistry of the troposphere, in Satellite Sensing of a Cloudy Atmosphere: Observing the Third Planet, edited by A. Henderson-Sellers, pp. 123-166, Taylor and Francis, London, 1984.

Logan, J. A., M. J. Prather, S. C. Wofsy, and M. B. McElroy, Tropospheric chemistry: A global perspective, J. Geophys. Res, , 86, 7210-7254, 1981.

Logan, J. A., Nitrogen oxides in the troposphere: global and reglonal budgets, J. Geophys. Res., 88, 10,785-10,807, 1983.

Schiff, H. I., D. R. Hastie, G. I. Mackay, T. Iguchi, and B. A. Ridley, Tunable diode laser systems for measuring trace gases in tropospheric air, Environ. Sci. Technol., 17, 352A-364A, 1983.

Schiff, H. I., G. W. Harris, and G. I. Mackay, Measurement of atmospheric gases by laser absorption spectrometry, in Chemistry of Acid Rain: Sources and Atmospheric Processes, Symp. Ser., Vol. 349, edited by R. W. Johnson and G. E. Gordon, Pp. 274-288, American Chemical Society, Washington D.C., 1987.

Schiff, H. I., D. R. Karecki, G. W. Harris, D. R. Hastie, and G. I. Mackay, A tunable diode laser system for aircraft measurements of trace gases, J. Geophys. Res., this issue.

Shipham, M. C., A. S. Bachmeier, and D. R. Cahoon, Meteorological conditions during the summer 1986 CITE 2 flight series, J.Geophys. Res., this issue.

Stedman D. H. and R. E. Shetter, The global budget of atmospheric nitrogen species, in Trace Atmospheric Constituents, Properties, Transformations and Fates, pp. 411-454, John Wiley, New York, 1983.

D. R. Hastie and H. I. Schiff, Department of Chemistry, New York University, North York, Ontario, Canada M3J 1 P3.

B. J. Huebert, Center for Atmospheric Chemistry Studies, Graduate School of Oceanography, University of Rhode Island, Narragansett, RI 02882 .

P. J. LeBel and S. A. Vay, NASA Langley

Research Center, Ma11 Stop 468, Hampton, VA 23665. S. E. VanBramer, Department of Chemistry, Colorado College, Colorado Springs, Co 80903.

(Received February 8, 1989; accepted April 27, 1989.) 